\title{
INTERNALISASI NILAI - NILAI RELIGIUS MELALUI KEGIATAN EKSTRAKURIKULER KEROHANIAN ISLAM DI SMP NEGERI 47 SURABAYA
}

\author{
Warsito Hadi 1 \\ IUIN Sunan Ampel Surabaya
}

\begin{abstract}
ABSTRAK
Penelitian ini bertujuan menganalisis pelaksanaan internalisasi nilai-nilai religius melalui kegiatan ekstrakurikuler kerohanian Islam di SMPN 47 Surabaya. Penelitian ini merupakan penelitian deskriptif kualitatif jenis studi kasus. Hasil penelitian menunjukkan, bahwa proses internalisasi nilai-nilai religius melalui kegiatan ekstrakurikuler kerohanian Islam mencakup nilai akidah, syariah, dan akhlak dengan menggunakan metode keteladanan, pembiasaan, pengawasan, nasihat dan hukuman. Kegiatan-kegiatannya meliputi: pemberian contoh berbusana muslimah, membiasakan siswa shalat jamaah dhuha dan ashar, membiasakan siswa melakukan shalat jumat, pondok romadhon, kepanitiaan zakat fitrah/mal, peringatan maulid Nabi Muhammad SAW, dan istighosah. Proses internalisasi melalui tiga tahap, yaitu transformasi nilai, transaksi nilai, dan transinternalisasi nilai. Proses internalisasi didukung oleh kerjasama yang harmonis dengan sesama guru, sebagian besar siswa berasal dari keluarga yang agamis dan ketersediaan saranaprasarana yang dibutuhkan siswa. Agar lebih efektif, penulis merekomendasikan beberapa hal: Pertama, haru ada sinergitas antara guru dan orang tua agar upaya internalisasi nilainilai agama Islam berkelanjutan di lingkungan keluarga; Kedua, perlu adanya evaluasi berkala, sehingga kekurangan dan kelebihannya dapat diketahui secara tepat.

Kata Kunci: Nilai Keislaman, Ekstrakurikuler Kerohanian Islam, Religiusitas.
\end{abstract}

\section{ABSTRACT}

This study aims to analyze the implementation of the internalization of religious values through extracurricular activities of Islamic spirituality at SMPN 47 Surabaya. This research is a descriptive qualitative case study type. The results showed that the process of internalizing religious values through extracurricular activities of Islamic spirituality includes the values of faith, sharia, and morals using exemplary methods, habituation, supervision, advice and punishment. The activities include: giving examples of Muslim dress, getting students used to praying in the Duha and Asr congregations, getting students to perform Friday prayers, pondok romadhon, zakat fitrah / maal, commemoration of the Prophet Muhammad SAW's birthday, and istighosah. The internalization process goes through three stages, namely value transformation, value transaction, and value transinternalization. The internalization process is supported by harmonious cooperation with fellow teachers, most students come from religious families and the availability of infrastructure needed by students. To be more effective, the authors recommend several things: First, there must be synergy between teachers and parents so that efforts to internalize Islamic religious values are sustainable in the family environment. Second, there needs to be periodic evaluation, so that the advantages and disadvantages can be identified precisely.

Keywords: Islamic Values, Extracurricular Islamic Spirituality, Religiosity. 


\section{A. Pendahuluan}

Dalam meningkatkan kualitas pendidikan yang memiliki landasan akan pentingnya nilai-nilai religius Islam, maka pendidikan itu akan memasukkan materimateri keagamaan dalam bentuk pengajaran di kelas (kurikuler) maupun di luar kelas berupa kegiatan ekstrakurikuler. Kegiatan kurikuler merupakan kegiatan pokok pendidikan yang di dalamnya terjadi proses belajar mengajar antara peserta didik dan guru untuk mendalami materi-materi ilmu pengetahuan yang berkaitan dengan tujuan pendidikan dan kemampuan yang hendak diperoleh siswa. Kegiatan kurikuler ini berupa serangkaian proses dalam rangka menyelenggarakan kurikulum pendidikan yang sedang diberlakukan atau dijalankan sebagai input pendidikan. Kegiatan ekstrakurikuler merupakan kegiatan yang dilakukan di luar kelas atau di luar jam pelajaran untuk menumbuhkembangkan sumber daya siswa baik yang berkaitan dengan aplikasi ilmu pengetahuan yang didapatkan siswa di dalam kelas maupun dalam pengertian khusus untuk membimbing siswa dalam mengembangkan potensi dan bakat yang ada dalam dirinya melalui kegiatan yang wajib maupun pilihan. ${ }^{1}$

Dalam kegiatan ekstrakurikuler terdapat kegiatan yang bersifat umum, yaitu kegiatan yang lebih kepada pembentukan jiwa intelektual siswa, dan ada kegiatan yang bersifat kerohanian Islam yaitu kegiatan yang dilaksanakan guna membentuk intelektual dan jiwa religius dalam diri siswa dengan menanamkan nilai-nilai religius Islam dalam setiap kegiatannya.

Kegiatan ekstrakurikuler kerohanian Islam di sini adalah berbagai kegiatan yang diselenggarakan dalam rangka memberikan arahan kepada siswa untuk dapat mengamalkan ajaran agama yang diperolehnya melalui kegiatan belajar di kelas, serta berbagai pendorong dalam membentuk sikap dan tingkah laku siswa sesuai dengan nilai-nilai religius Islam. Dengan kata lain, tujuan dasar kegiatan ekstrakurikuler kerohanian Islam adalah untuk membentuk manusia

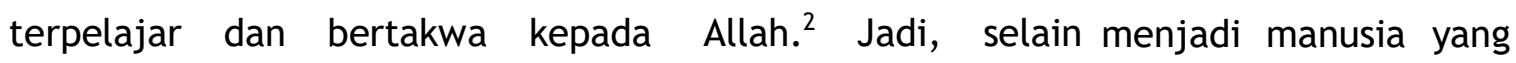
berilmu pengetahuan, peserta didik juga diharapkan menjadi manusia yang mampu menjalankan perintah agama dan menjauhi larangannya. ${ }^{3}$

\footnotetext{
1 Departemen Agama RI, Panduan Kegiatan Ekstrakurikuler Pendidikan Agama Islam (Jakarta: Direktorat Jenderal Kelembagaan Agama Islam, 2005), 3-4.

2 Ibid., 9.

${ }^{3}$ Baca, Evi Fatimatur Rusydiyah, Aliran Dan Paradigma Pemikiran Pendidikan Agama Islam Kontemporer (Surabaya: Sunan Ampel Press, 2019).
} 
Pengembangan kegiatan ekstrakurikuler kerohanian Islam ditujukan sebagai upaya memantapkan pembentukan kepribadian siswa. Upaya tersebut antara lain melalui kegiatan-kegiatan: doa bersama sebelum memulai dan sesudah selesai kegiatan belajar mengajar, tadarus Alquran (secara bersama-sama atau bergantian) selama 15-20 menit sebelum waktu belajar jam pertama dimulai yang dipimpin oleh guru yang mengajar pada jam pertama, shalat Dzuhur berjamaah dan kultum (kuliah tujuh menit), atau pengajian/bimbingan keagamaan secara berkala, mengisi peringatan hari-hari besar keagamaan, mengintensifkan praktik ibadah dan mengadakan pengajian kitab di luar waktu terjadwal. ${ }^{4}$

Pengembangan kegiatan ekstrakurikuler merupakan bagian dari keseluruhan pengembangan institusi sekolah. Berbeda dengan petunjuk pengaturan kegiatan intrakurikuler yang secara jelas disiapkan dalam perangkat kurikulum, kegiatan ekstrakurikuler lebih mengandalkan pada inisiatif sekolah. Secara yuridis, pengembangan kegiatan ekstrakurikuler memiliki landasan hukum yang kuat, karena diatur dalam surat Keputusan Menteri (Kepmen) yang harus dilaksanakan oleh sekolah dan madrasah. Salah satu Keputusan Menteri Pendidikan Nasional RI No. 125/U/2002 tentang Kalender Pendidikan dan Jumlah Belajar Efektif di Sekolah. Pada bagian keputusan dijelaskan pada Lampiran Keputusan Mendiknas Nomor 125/U/2002 Tanggal 31 Juli 2002, yaitu:

"Liburan sekolah atau madrasah selama bulan Ramadhan diisi dan dimanfaatkan untuk melaksanakan berbagai kegiatan yang diarahkan pada peningkatan akhlak mulia, pemahaman, pendalaman dan amaliah agama, termasuk kegiatan ekstrakurikuler lainnya yang bermuatan moral". ${ }^{5}$

Dengan adanya kegiatan ekstrakurikuler yang bersifat kerohanian Islam dapat menjadi suatu proses penyadaran nilai-nilai agama Islam, bahkan sampai pada internalisasi nilai-nilai agama Islam yang dapat memberikan pengaruh terhadap sikap dan tingkah laku siswa dalam menjalankan kehidupan sehari-harinya.

Internalisasi adalah menyatukan nilai dalam diri seseorang, atau dalam bahasa psikologi merupakan penyesuaian keyakinan, nilai, sikap, perilaku (tingkah laku), praktik dan aturan baku pada diri seseorang. ${ }^{6}$ Nilai-nilai religius adalah nilai luhur yang ditransfer dan diadopsi ke dalam diri. Jadi, internalisasi nilai-nilai agama Islam adalah suatu proses memasukan nilai-nilai agama secara penuh ke dalam hati,

${ }^{4}$ Abdul Rachman Shaleh, Madrasah dan Pendidikan Anak Bangsa : Visi, Misi,dan Aksi (Jakarta :PT. Raja Grafindo Persada, 2005), 170.

${ }^{5}$ Rohmat Mulyana, Mengartikulasikan Pendidikan Nilai (Bandung: CV Alfabeta, 2004), 211-212.

${ }^{6}$ Lihat, Muh. Khoirul Rifa'i, "Internalisasi Nilai-nilai Religius Berbasis Multikultural dalam Membentuk Insan Kamil”, Jurnal Pendidikan Agama Islam (Journal of Islamic Education Studies), Vol. 4 No. 1 (2016). 
sehingga ruh dan jiwa bergerak berdasarkan ajaran agama Islam. Internalisasi nilai-nilai religius Islam itu terjadi melalui pemahaman ajaran agama secara utuh, dan diteruskan dengan kesadaran akan pentingnya agama Islam, serta ditemukannya posibilitas untuk merealisasikannya dalam kehidupan nyata. ${ }^{7}$

Di antara penyebab dunia pendidikan kurang mampu menghasilkan lulusannya yang diharapkan adalah karena dunia pendidikan selama ini hanya membina kecerdasan intelektual, wawasan dan keterampilan semata, tanpa diimbangi dengan membina kecerdasan emosional. ${ }^{8}$

Kondisi seperti di atas tentu sangat berpengaruh terhadap sistem dan proses pendidikan di sekolah, sehingga tujuan pendidikan tidak dapat tercapai dengan tepat. Tujuan pendidikan adalah meningkatkan kualitas manusia, yaitu manusia yang beriman dan bertaqwa kepada tuhan dan berdisiplin, beretos kerja, profesional, bertanggung jawab, terampil serta mandiri yang memerlukan usaha secara maksimal dari berbagai komponen pendidikan. ${ }^{9}$ Untuk itu, dalam mencapai tujuan manusia yang beriman dan bertaqwa, kepala sekolah dan guru serta stafstaf yang lainnya melakukan berbagai usaha agar nilai-nilai keagamaan pada siswa benar-benar terinternalisasi.

Untuk memudahkan pencapaian nilai-nilai keimanan dan ketaqwaan, para pendidik menyederhanakan tema-tema nilai ke dalam sejumlah program dan peristiwa pendidikan pada situasi praktis. Nilai menjadi kekuatan integratif yang mendorong dan memberikan arah perilaku sivitas sekolah. Oleh karena itu, nilai selain mendorong dan mengarahkan kepala sekolah dan guru untuk melakukan penyadaran nilai, juga menjadi kekuatan internal dalam diri siswa untuk menemukan dirinya. ${ }^{10}$

Jadi, kegiatan ekstrakurikuler kerohanian Islam merupakan salah satu cara yang dapat digunakan dalam menjalankan pelaksanaan internalisasi nilai-nilai agama Islam, karena dengan kegiatan ekstrakurikuler kerohanian Islam siswa mendapatkan suatu pengetahuan dengan cara mengalami suatu peristiwa yang menjadikan siswa lebih memahami situasi yang dihadapinya sehingga siswa dapat mengaplikasikan pengetahuannya dalam menjalankan kehidupan sehari-harinya sesuai dengan nilai-

${ }^{7}$ Muhammad Alim, Pendidikan Agama Islam Upaya Pembentukan Pemikiran dan Kepribadian Muslim (Bandung: PT. Remaja Rosdakarya, 2006),10.

8 Abuddin Nata, Manajemen Pendidikan: Mengatasi Kelemahan Pendidikan Islam di Indonesia (Jakarta: Kencana, 2007), 45-46.

${ }^{9}$ M. Arif Hanafi, et, al., "Optimalisasi Kegiatan Keagamaan dalam Meningkatkan Sikap Spiritual Siswa di SMPN 3 Waru Sidoarjo", (2021).

${ }^{10}$ Mulyana, Mengartikulasikan Pendidikan Nilai, 256. 
nilai religius Islam yang telah ditanamkan dalam diri siswa melalui berbagai kegiatan ekstrakurikuler kerohanian Islam.

Proses internalisasi nilai-nilai agama Islam melalui kegiatan ekstrakurikuler kerohanian Islam ini memiliki tujuan untuk menggali dan memotivasi siswa dalam bidang tertentu serta menyadarkan siswa akan kesadaran beragama sehingga tingkah lakunya sesuai dengan norma-norma atau nilai-nilai yang telah dirumuskan dalam pegangan umat islam. Oleh karena itu, kegiatan ekstrakurikuler kerohanian Islam harus disesuaikan dengan hobi serta kondisi siswa. Kegiatan ekstrakurikuler kerohanian Islam juga dapat membantu dan meningkatkan pengembangan wawasan anak didik khusus dalam bidang Pendidikan Agama Islam, dengan demikian kegiatan ekstrakurikuler kerohanian Islam dapat meningkatkan keimanan dan ketaqwaan kepada Allah. Sebagaimana dikemukakan Taylor yang disitir oleh Henry bahwa individu mendapatkan pendidikan melalui cara saat ia meluangkan waktunya dan dengan situasi di mana dia dilibatkan, atau dalam peristiwa yang seketika dialaminya. ${ }^{11}$

Ditelaah dari perspektif pendidikan nilai, dapat diartikulasikan ke dalam tiga lingkup pendidikan nilai yaitu: pertama, pendidikan nilai melalui cara yang terencana dengan melibatkan sejumlah pertimbangan nilai-nilai edukatif, baik yang mencakup dalam manajemen pendidikan maupun dalam kurikulum pendidikan. Kedua, pendidikan nilai melalui situasi yang berpengaruh terhadap perkembangan pengalaman dan kesadaran nilai pada siswa. Ketiga, pendidikan nilai melalui peristiwa seketika yang dialami siswa, artinya berlangsung sejumlah kejadian yang tidak terduga, sukarela, dan spontanitas.

Berdasarkan latar belakang di atas, penulis tertarik melakukan penelitian lebih mendalam tentang proses internalisasi nilai-nilai religius Islam melalui kegiatan ekstrakurikuler kerohanian Islam serta faktor pendukung dan penghambatanya di SMP Negeri 47 Surabaya. Oleh karena itu masalah yang dikaji dalam penelitian ini: (1) Bagaimana proses internalisasi nilai-nilai relegius melalui kegiatan ekstrakurikuler kerohanian Islam; dan (2) Apa saja faktor pendukung dan penghambat internalisasi nilai-nilai religius melalui kegiatan ekstrakurikuler kerohanian di SMP Negeri 47 Surabaya?

\footnotetext{
11 Ibid., 212.
} 


\section{B. Nilai-nilai Religius sebagai Substansi Pendidikan}

Nilai adalah harga. Sesuatu barang bernilai tinggi karena barang itu "harganya" tinggi. Bernilai artinya berharga. Jelas, segala sesuatu tentu bernilai, karena segala sesuatu berharga, hanya saja ada yang harganya rendah ada yang tinggi. ${ }^{12}$ Nilai ialah prinsip atau hakikat yang menentukan harga atau nilai dan makna bagi sesuatu. Dalam kehidupan akhlak manusia yang menentukan nilai manusia, harga diri, dan amal serta sikapnya ialah prinsip-prinsip tertentu seperti kebenaran, kebaikan, kesetiaan, keadilan, persaudaraan, keprihatinan dan kerahiman. ${ }^{13}$

Nilai adalah suatu seperangkat keyakinan atau perasaan yang diyakini sebagai suatu identitas yang memberikan corak yang khusus kepada pola pemikiran, perasaan, keterikatan maupun perilaku. ${ }^{14}$ Dengan demikian nilai adalah bagian dari potensi manusiawi seseorang. Nilai adalah standar tingkah laku, keindahan, keadilan, dan efisiensi yang mengikat manusia dan sepatutnya dijalankan serta dipertahankan.

Kata religius tidak identik dengan kata agama, namun lebih kepada keberagaman. Keberagaman, menurut Muhaimin dkk, lebih melihat aspek yang di dalam lubuk hati nurani pribadi, sikap personal yang sedikit banyak misteri bagi orang lain, karena menafaskan intimitas jiwa, cita rasa yang mencakup totalitas ke dalam pribadi manusia. ${ }^{15}$

Menurut Glock \& Stark yang dikutip oleh muhaimin menjelaskan bahwa: Agama adalah sistem simbol, sistem keyakinan, sistem nilai dan sistem perilaku yang terlembagakan, yang semuanya itu berpusat pada persoalan-persoalan yang dihayati sebagai yang paling maknawi (ultimate meaning). Menurut Glock \& Stark, ada lima macam dimensi keberagamaan, yaitu: 1) Dimensi keyakinan, berisi pengharapan-pengharapan di mana orang religius berpegang teguh pada pandangan teologis tertentu dan mengakui kebenaran doktrin tertentu, 2) Dimensi praktik agama, yang mencakup perilaku pemujaan, ketaatan dan hal-hal yang dilakukan orang untuk menunjukkan komitmen terhadap agama yang dianutnya, 3) Dimensi pengalaman, berkaitan dengan pengalaman keagamaan, perasaan-perasaan, presepsi-presepsi dan sensasi-sensasi yang dialami seseorang, 4) Dimensi pengetahuan

\footnotetext{
${ }^{12}$ Ahmad Tafsir, Filsafat Pendidikan Islam, Integrasi Jasmani, Rohani, dan Kalbu Memanusiakan Manusia (Bandung: PT. Remaja Rosdakarya, 2012), 48

13 Abdul Aziz, Filsafat Pendidikan Islam: Sebuah Gagasan Membangun Pendidikan Islam (Surabaya: eLKAF,2006), 102.

${ }^{14}$ Abu Ahmadi dan Noor Salimi, Dasar-Dasar Pendidikan Agama Islam (Jakarta: Bumi Aksara, 2008), 202.

${ }^{15}$ Muhaimin et.al, Paradigma Pendidikan Islam (Bandung: Remaja Rosdakarya,2012), 287.
} 
agama, mengacu kepada harapan orang- orang yang beragama paling tidak memiliki sejumlah minimal pengetahuan mengenai dasar-dasar keyakinan, ritusritus, kitab suci, dan tradisi-tradisi, 4) Dimensi pengamalan, mengacu pada identifikasi akibat-akibat keyakinan keagamaan, praktik, pengalaman, dan pengetahuan seseorang dari hari ke hari. ${ }^{16}$

Agama adalah risalah yang disampaikan Tuhan kepada Nabi sebagai petunjuk bagi manusia dan hukum-hukum sempurna untuk dipergunakan manusia dalam menyelenggarakan tatacara hidup yang nyata serta mengatur hubungan dan tanggung jawab kepada Allah, kepada masyarakat dan alam sekitarnya. ${ }^{17}$ Agama sebagai sumber sistem nilai, merupakan petunjuk, pedoman dan pendorong bagi manusia untuk memecahkan masalah hidupnya seperti dalam ilmu agama, politik, ekonomi, sosial, budaya dan militer sehingga terbentuk pola motivasi, tujuan hidup dan perilaku manusia yang menuju kepada keridlaan Allah (akhlak).

Berdasarkan uraian di atas dapat disimpulkan bahwa nilai religius merupakan standar tingkah laku yang mengikat manusia. Oleh karena itu sepatutnya dijalankan serta dipertahankan sesuai dengan syariat agama Islam yang berdasarkan pada ketentuan Allah SWT.

Ada beberapa nilai-nilai keagamaan mendasar yang harus ditanamkan pada peserta didik dan kegiatan menanamkan nilai-nilai pendidikan inilah yang sesungguhnya menjadi inti pendidikan keagamaan. Di antara nilai-nilai yang penting dimiliki oleh peserta didik antara lain:

\section{Nilai Aqidah}

Aqidah secara etimologi berarti yang terikat. Setelah terbentuk menjadi kata, aqidah berarti perjanjian yang teguh dan kuat, terpatri dan tertanam di dalam lubuk hati yang paling dalam. Dengan demikian aqidah adalah urusan yang wajib diyakini kebenarannya oleh hati, menenteramkan jiwa, dan menjadi keyakinan yang tidak bercampur dengan keraguan. ${ }^{18}$ Aqidah itu selanjutnya harus tertanam dalam hati, sehingga dalam segala kegiatan yang dilakukan oleh manusia diniatkan untuk ibadah kepada Allah dan bernilai ibadah pula. Aqidah yang tertanam dalam jiwa seseorang muslim akan senantiasa menghadirkan dirinya dalam pengawasan Allah semata-mata, karena itu perilaku-

\footnotetext{
16 Ibid., 293.

17 Ahmadi dan Salimi, Dasar-Dasar Pendidikan, 4.

${ }^{18}$ Alim, Pendidikan Agama Islam, 124.
} 
perilaku yang tidak dikehendaki Allah akan selalu dihindarkannya.

Istilah aqidah sering pula disebut tauhid. Istilah tauhid berasal dari bahasa Arab yang berarti mengesakan, mengandung pengertian mengesakan Allah SWT. Artinya, pengakuan bahwa di alam semesta ini tiada Tuhan selain Allah. ${ }^{19}$

2. Nilai Syari'ah

Secara redaksional pengertian syariah adalah "the part of the water place" yang berarti tempat jalannya air, atau secara maknawi adalah sebuah jalan hidup yang telah ditentukan Allah SWT., sebagai panduan dalam menjalan kehidupan di dunia untuk menuju kehidupan akhirat. Kata syariah menurut pengertian hukum Islam berarti hukum-hukum dan tata aturan yang disampaikan Allah agar ditaati hamba-hambaNya. Syariah juga diartikan sebagai satu sistem norma llahi yang mengatur hubungan manusia dengan tuhan, hubungan manusia dengan manusia, serta hubungan manusia dengan alam lainnya. ${ }^{20}$

Kaidah syariah yang mengatur hubungan langsung dengan Tuhan disebut ubudiyah atau ibadah dalam arti khusus. Kaidah syariah Islam yang mengatur hubungan manusia dengan manusia dan alam sekitar disebut muamalah. Jadi secara umum lingkup syariah mencakup dua hal yakni ibadah dan muamalah.

3. Nilai Akhlaq

Kata akhlak diambil dari bahasa arab khuluqun yang berarti perangai, tabiat, adat, dan khalqun yang berarti kejadian, buatan, ciptaan. Adapun pengertian akhlak secara terminologis, menurut Imam al-Ghazali dalam kitabnya Ihya' Ulum al-Din menyatakan akhlak adalah gambaran tingkah laku dalam jiwa yang dari padanya lahir perbuatan-perbuatan dengan mudah tanpa memerlukan pemikiran dan pertimbangan. ${ }^{21}$

Akhlak dibagi menjadi dua bagian yaitu akhlak terpuji dan akhlak tercela. Akhlak terpuji merupakan tingkah laku yang berdasarkan pada norma-norma yang berlaku dalam ajaran Islam dan tidak terpengaruh oleh hawa nafsu yang menjurus pada perbuatan tercela. Sedangkan akhlak tercela berasal dari dorongan hawa nafsu yang berasal dari dorongan syaitan yang membawa

\footnotetext{
19 Ibid., 126.

${ }^{20}$ Alim, Pendidikan Agama Islam, 139.

21 Ibid., 151.
} 
kita pada hal-hal yang tercela dan merugikan diri sendiri maupun orang lain, seperti sombong, su'udzon, malas, berbohong, dan lain-lain.

Sementara itu, menurut obyek dan sasarannya, akhlak dapat digolongkan menjadi tiga macam, yaitu sebagai berikut: (1) Akhlak kepada Allah, antara lain beribadah kepada Allah, berdzikir, berdoa, tawakal, dan tawadhu'(rendah hati) kepada Allah; (2) Akhlak kepada manusia, termasuk dalam hal akhlak kepada Rasulullah, orang tua, diri sendiri, keluarga, tetangga, dan akhlak kepada masyarakat; (3) Akhlak kepada lingkungan hidup, seperti sadar dan memelihara kelestarian lingkungan hidup, menjaga dan memanfaatkan alam, terutama hewani dan nabati. ${ }^{22}$

Akhlak dalam diri manusia timbul dan tumbuh dari dalam jiwa, kemudian berbuah ke segenap anggota yang menggerakkan amal-amal serta menghasilkan sifat-sifat yang baik serta menjauhi segala larangan terhadap sesuatu yang buruk yang membawa manusia ke dalam kesesatan. Puncak dari akhlak itu adalah pencapaian prestasi berupa: (1) Irsyad, yakni kemampuan membedakan antara amal yang baik dan buruk; (2) Taufiq, yaitu perbuatan yang sesuai dengan tuntunan Rasulullah dengan akal sehat; (3) Hidayah, yaitu gemar melakukan perbuatan baik dan terpuji serta menghindari yang buruk dan tercela. ${ }^{23}$

\section{Menumbuhkankan Sikap Religius pada Peserta Didik}

Pengetahuan tentang nilai-nilai religius yang diperoleh dalam proses belajar mengajar di kelas hanya sedikit saja berpengaruh terhadap tertanamnya nilai-nilai religius pada peserta didik. Agar nilai-nilai yang dipelajari tersebut dapat menyatu pada jiwa peserta didik maka guru harus mampu menginternalisasikan nilai-nilai religius, yang kemudian nilai tersebut akan tumbuh dan berkembang pada diri peserta didik, sehingga dapat mengkhayati nilai agama sebagai nilai yang hidup dalam keseharian.

Internalisasi diartikan sebagai penggabungan atau penyatuan sikap, standar tingkah laku, pendapat, dan seterusnya di dalam kepribadian. ${ }^{24}$ Ahmad Tafsir membedakan antara internalisasi dan personalisasi, namun kedua proses tersebut harus berjalan bersamaan dan menjadi satu kesatuan yang utuh. Internalisasi

22 Aminuddin, Pendidikan Agama Islam: Untuk Perguruan Tinggi Umum (Bogor: Ghalia Indonesia, 2005), 153.

${ }^{23}$ Zulkarnain, Transformasi Nilai-Nilai, 29.

24 J.P. Chaplin, Kamus Lengkap Psikologi, (Jakarta: Rajawali press, 2011), 256. 
merupakan upaya memasukkan pengetahuan (knowing) dan keterampilan melaksanakan (doing) dari daerah ektern ke intern, dikatakan personalisasi karena upaya tersebut berupa usaha untuk menjadikan pengetahuan dan keterampilan menyatu dengan pribadi seseorang. ${ }^{25}$ Jadi Internalisasi nilai merupakan proses penanaman nilai kedalam jiwa seseorang sehingga nilai tersebut dapat menyatu pada kepribadian seseorang yang tercermin pada sikap dan prilaku dalam kehidupan sehari-harinya.

Internalisasi nilai agama adalah suatu proses memasukkan nilai agama secara penuh ke dalam hati, sehingga ruh dan jiwa bergerak berdasarkan ajaran agama. Internalisasi agama terjadi melalui pemahaman ajaran agama secara utuh, dan diteruskan dengan kesadaran akan pentingnya ajaran agama, serta ditemukan posibilitas untuk merealisasikannya dalam kehidupan nyata. ${ }^{26}$

Masalah internalisasi ini tidak hanya berlaku pada pendidikan agama saja, tetapi pada semua aspek pendidikan, pada pendidikan pra-sekolah, pendidikan sekolah, pendidikan latihan perguruan dan lain-lain. Oleh karena itu agar proses internalisasi dapat berjalan dengan baik perlu adanya kerjasama semua pihak, baik sekolah, masyarakat, maupun keluarga. Internalisasi nilai-nilai terjadi melalui beberapa tahap: Pertama, Tahap transformasi nilai. Pada tahap ini guru sekadar menginformasikan nilai-nilai yang baik dan yang kurang baik kepada siswa, yang semata-mata merupakan komunikasi verbal. ${ }^{27}$ Transformasi nilai ini sifatnya hanya pemindahan pengetahuan dari pendidik ke siswanya. Nilai-nilai yang diberikan masih berada pada ranah kognitif dan pengetahuan ini dimungkinkan hilang jika ingatan seseorang tidak kuat.

Kedua, Tahap transaksi nilai. Tahap ini merupakan tahap pendidikan nilai dengan jalan melakukan komunikasi dua arah antara siswa dan guru. Dalam transaksi ini guru dan siswa sama-sama memiliki sifat yang aktif. Dalam tahap ini guru tidak hanya menyajikan informasi tentang nilai yang baik dan buruk, tetapi juga terlibat untuk melaksanakan dan memberikan contoh amalan yang nyata, dan siswa diminta memberikan respons yang sama, yakni menerima dan mengamalkan nilainilai itu. ${ }^{28}$ Pada tahap ini guru dapat memberikan pengaruh pada siswa untuk mengamalkan apa yang dicontohkan oleh gurunya, dengan begitu nilai-nilai religius

\footnotetext{
${ }^{25}$ Ahmad Tafsir, Filsafat Pendidikan, 229.

${ }^{26}$ Alim, Pendidikan Agama Islam, 10.

${ }^{27}$ Muhaimin et.al, Paradigma Pendidikan, 178.

${ }^{28}$ Nia Indah Purnamasari, "Komparasi Konsep Sosiokulturalisme dalam Pendidikan: Perspektif Barat dan Islam”, EL-BANAT: Jurnal Pemikiran dan Pendidikan Islam, Vol. 9 No. 2 (2019), 238-261.
} 
akan tertanam pada diri siswa dan mampu mengamalkannya dalam kehidupan sehari-hari.

Ketiga, Tahap transinternalisasi nilai. Tahap ini jauh lebih dalam dari sekedar transaksi. Dalam tahap ini penampilan guru dihadapan siswa bukan lagi sosok fisiknya, melainkan sikap mentalnya (kepribadiannya). Demikian juga siswa merespons kepada guru bukan hanya gerakan/penampilan fisiknya, melainkan sikap mental dan kepriadiannya. Dalam transinternalisasi ini adalah komunikasi dua kepribadian yang masing-masing terlibat aktif. ${ }^{29}$ Dalam tahap ini pendidik harus betul-betul memperhatikan sikap dan prilakunya, baik di depan peserta didik maupun dalam kehidupan sehari-harinya. Hal ini disebabkan, siswa cenderung meniru sikap dan kepribadian yang ada pada gurunya, karena guru dianggap sebagai panutan mereka.

Proses dari transinternalisasi itu mulai dari yang sederhana sampai yang kompleks, yaitu mulai dari: Menyimak, yakni kegiatan siswa utuk bersedia menerima adanya stimulus yang berupa nilai-nilai baru; Menanggapi, yakni kesediaan siswa untuk merespon nilai-nilai yang ia terima. Memberi nilai, siswa mampu memberikan makna baru terhadap nilai-nilai yang muncul dengan criteria nilai-nilai yang diyakini kebenarannya; Mengorganisasikan nilai, aktivitas siswa untuk mengatur berlakunya system nilai yang ia yakini sebagai kebenaran dalam laku kepribadiannya sendiri; Karakteristik nilai, yakni dengan membiasakan nilai-nilai yang benar yang diyakini, dan yang telah terorganisir sehingga nilai tersebut sudah menjadi watak, yang tidak dapat dipisahkan lagi dari kepribadiannya. ${ }^{30}$

Pendidikan Agama dimaksudkan untuk peningkatan potensi religius dan membentuk peserta didik agar menjadi manusia yang beriman dan bertaqwa kepada Tuhan Yang Maha Esa dan berakhlak mulia. Peningkatan potensi religious mencangkup pengenalan, pemahaman, dan penanaman nilai-nilai keagamaan, serta pengamalan nilai-nilai tersebut dalam kehidupan. ${ }^{31}$

Banyak cara yang dapat digunakan untuk menginternalisasikan nilai-nilai keagamaan kepada peserta didik. Penanaman nilai tidak hanya melalui proses pengajaran saja. Pengajaran sebatas penambahan pengetahuan dan pembinaan keterampilan. Jadi pengajaran belum mencapai aspek sikap dan kepribadian siswa

\footnotetext{
29 lbid.

${ }^{30}$ Muhaimin et.al, Paradigma Pendidikan, 178-179.

${ }^{31}$ Asmaun Sahlan, Mewujudkan Budaya Religius di Sekolah: Upaya Mengembangkan PAl dari Teori ke Aksi (Malang: UIN-Maliki Press, 2010), 29.
} 
di mana nilai itu akan menyatu. Beberapa usaha untuk menanamkan nilai keagamaan di antaranya, pemberian keteladanan, pembiasaan, penciptaan suasana lingkungan yang religius, dan pemberian motivasi.

\section{Proses Internalisasi Nilai-nilai Religius melalui Kegiatan Ekstrakurikuler Kerohanian Islam}

Kegiatan ekstrakurikuler kerohanian Islam di SMPN 47 Surabaya merupakan bagian tidak terpisahkan dengan program Pendidikan Agama Islam (PAI) Intrakurikuler, sebab PAl harus dilakukan secara komprehensif dan menyeluruh. Komprehensif, artinya selain melalui kurikuler juga melalui ekstrakurikuler. Menyeluruh, artinya, selain di sekolah penanaman nilai-nilai agama Islam juga harus dilakukan di lingkungan keluarga dan di masyarakat. Orang tua siswa harus mendukung penuh penanaman nilai-nilai Islam kepada siswa dengan mengkondisikan lingkungan keluarga yang islami agar anak-anak membiasakan shalat dhuha, melakukan shalat wajib, shalat berjamaah, jumatan, puasa wajib dan sunnah, membayar zakat fitrah, suka menolong dan berperilaku yang karimah.

Menurut Kepala Sekolah, proses internalisasi nilai-nilai Islam kepada siswa yang dilakukan dalam kegiatan ekstrakurikuler antara lain pembiasaan shalat jamaah, shalat jumat, pondok romadhon, penyelenggaraan zakat fitrah/mal, dan peringatan Maulid Nabi Muhammad SAW. ${ }^{32}$ Koordinator Guru PAI menambahkan dua kegiatan yaitu: Pemberian contoh berpakaian Muslimah, dan Istighosah. ${ }^{33}$

Ditinjau dari objek penanaman nilai-nilai kerohanian Islam dapat didiskusikan sgai berikut.

1. Penanaman nilai aqidah

Aqidah berarti perjanjian yang teguh dan kuat, terpatri dan tertanam di dalam lubuk hati yang paling dalam. Dengan demikian aqidah adalah urusan yang wajib diyakini kebenarannya oleh hati, menenteramkan jiwa, dan menjadi keyakinan yang tidak bercampur dengan keraguan. Aqidah itu selanjutnya harus tertanam dalam hati, sehingga dalam segala kegiatan yang dilakukan oleh manusia diniatkan untuk ibadah kepada Allah dan bernilai ibadah pula. Aqidah yang tertanam dalam jiwa seseorang muslim akan senantiasa menghadirkan dirinya dalam pengawasan Allah semata-mata, karena itu perilaku-perilaku yang

\footnotetext{
${ }^{32}$ Kepala SMP Negeri 47 Surabaya, Wawancara, Surabaya, 11 Februari 2020.

${ }^{33}$ Koordinator Guru PAI SMP Negeri 47 Surabaya, Wawancara, Surabaya, 5 Februari 2020.
} 
tidak dikehendaki Allah akan selalu dihindarkannya. Oleh karena itu apabila penyelenggara negara memiliki aqidah yang kuat niscaya Komisi Pemberantasan Korupsi tidak perlu dibentuk sebab tidak akan dijumpai praktek tindak pidana korupsi.

Istilah aqidah sering pula disebut tauhid. Istilah tauhid berasal dari bahasa Arab yang berarti mengesakan. Istilah tauhid mengandung pengertian mengesakan Allah SWT. Artinya, pengakuan bahwa di alam semesta ini tiada Tuhan selain Allah. ${ }^{34}$ Berjiwa tauhid adalah tujuan pendidikan Islam yang harus ditanamkan pada peserta didik, ${ }^{35}$ sesuai firman Allah dalam QS Luqman:13. Keseluruhan kegiatan ekstrakurikuler kerohaniahan Islam di SMPN 47 Surabaya merupakan upaya menanamkan nilai-nilai aqidah, selain nilai syariah dan akhlak.

Dalam kegiatan pemberian contoh berpakain muslimah misalnya, jelas kegiatan ini didasarkan atas perintah Allah Swt untuk menutup aurat bagi wanita Muslimah sebagaimana firman Allah Swt dalam QS. An-Nur, 31:

\begin{abstract}
"Katakanlah kepada wanita yang beriman: "Hendaklah mereka menahan pandangannya, dan memelihara kemaluannya, dan janganlah mereka menampakkan perhiasannya, kecuali yang [biasa] nampak daripadanya. Dan hendaklah mereka menutupkan kain kudung ke dadanya, dan janganlah menampakkan perhiasannya, kecuali kepada suami mereka, atau ayah mereka, atau ayah suami mereka, atau putera-putera mereka, atau putera-putera suami mereka, atau saudara-saudara laki-laki mereka, atau putera-putera saudara laki-laki mereka, atau putera-putera saudara perempuan mereka, atau wanita-wanita Islam, atau budak-budak yang mereka miliki, atau pelayan-pelayan laki-laki yang tidak mempunyai keinginan [terhadap wanita] atau anak-anak yang belum mengerti tentang aurat wanita. Dan janganlah mereka memukulkan kakinya agar diketahui perhiasan yang mereka sembunyikan. Dan bertaubatlah kamu sekalian kepada Allah, hai orang-orang yang beriman supaya kamu beruntung. (QS. An-Nur : ayat 31).
\end{abstract}

Dalam kegiatan pembiasaan shalat berjamaah dilihat dari prosedur melakukan shalat berjamaah termasuk upaya penanaman nilai-nilai syareat, namun dilihat dari ajaran Islam bahwa pahala orang yang melakukan shalat berjamaah jauh lebih banyak dibanding shalat sendirian adalah merupakan penanaman nilainilai aqidah yang bersumber dari sunnah Rasullullah SAW.

2. Penanaman Nilai-nilai Syareat Islam

Kata syariah menurut pengertian hukum Islam berarti hukum-hukum dan tata aturan yang disampaikan Allah agar ditaati hamba-hambaNya. Syariah juga diartikan sebagai satu sistem norma llahi yang mengatur hubungan manusia

\footnotetext{
34 Muhammad Alim, Pendidikan Agama Islam: Upaya Pembentukan Pemikiran dan Kepribadian Muslim (Bandung: PT Remaja Rosdakarya, 2011), 126.

${ }^{35}$ Zaini Tamin AR, "Teologi Pengembangan Pemuda; Membumikan Tauhid sebagai Dasar Kesalihan Sosial”, Mukammil : Jurnal Kajian Keislaman, Vol. 1 No. 2 (2018): 121-142.
} 
dengan tuhan, hubungan manusia dengan manusia, serta hubungan manusia dengan alam lainnya. ${ }^{36}$

Firman Allah dalam QS. Al-Jaatsiyah ayat 18:

"Kemudian Kami jadikan kamu berada di atas suatu syariat (peraturan) dari urusan (agama itu), Maka ikutilah syariat itu dan janganlah kamu ikuti hawa nafsu orang-orang yang tidak mengetahui."

Penanaman nilai-nilai syareat Islam dalam kegiatan ekstrakurikuler kerohanian Islam yang dilakukan SMPN 47 Surabaya hampir semuanya bermuatan penanaman nilai-nilai syareat Islam, meliputi: syareat menutup aurat bagi Muslimah, shalat wajib dan sunnah, berpuasa, zakat fitrah, membaca al-Quran, dan syareat bermuamalah. Kaidah syariah yang mengatur hubungan langsung dengan Tuhan disebut ubudiyah atau ibadah dalam arti khusus, sedangkan kaidah syariah Islam yang mengatur hubungan manusia dengan manusia dan alam sekitar disebut muamalah. Jadi secara umum lingkup syariah mencakup dua hal yakni ibadah dan muamalah, ${ }^{37}$ dan nilai-nilai syariah tersebut telah ditanamkan kepada siswa dalamkegiatan ekstrakurikuler kerohanian Islam di SMPN 37 Surabaya.

3. Penanaman Nilai-nilai Akhlak

Akhlak adalah gambaran tingkah laku dalam jiwa yang dari padanya lahir perbuatan-perbuatan dengan mudah tanpa memerlukan pemikiran dan pertimbangan. ${ }^{38}$ Akhlak dibagi menjadi dua bagian yaitu akhlak terpuji (akhlaqul Mahmudah) dan akhlak tercela (akhlaqul Madzmumah). Akhlak terpuji merupakan tingkah laku yang berdasarkan pada norma-norma yang berlaku dalam ajaran Islam dan tidak terpengaruh oleh hawa nafsu yang menjurus pada perbuatan tercela. Sedangkan akhlak tercela berasal dari dorongan hawa nafsu yang berasal dari dorongan syaitan yang membawa kita pada hal-hal yang tercela dan merugikan diri sendiri maupun orang lain, seperti sombong, su'udzon, malas, berbohong, dan lain-lain.

Penanaman nilai-nilai akhlak dalam kegiatan ekstrakurikuler kerohanian Islam di SMPN 37 Surabaya dilakukan di antaranya dalam kegiatan pondok romadhon. Materi yang disajikan dalam kegiatan tersaebut yang terkait dengan

\footnotetext{
36 Ibid., 139.

${ }^{37}$ Alim, Pendidikan Agama Islam, 143-144.

38 Ahmad Yusam Thobroni, “Etika Pelajar Dalam Perspektif Ibn Jama'ah", Jurnal Pendidikan Agama Islam (Journal of Islamic Education Studies), Vol. 1 No. 2 (2013).
} 
penanaman nilai-nilai akhlak antara lain: (1) Bimbingan keimanan dan kepribadian muslim; (2) Bimbingan Budi Pekerti/Akhlaq; dan (3) bimbingan kewajiban tolong menolong.

Pentingnya penanaman nilai-nilai akhlak ini didasarkan atas beberapa perintah Allah Swt. Sebagai berikut:

a. QS Ali Imron:133-134

" Dan bersegeralah kamu kepada ampunan dari Tuhanmu dan kepada surga yang luasnya seluas langit dan bumi yang disediakan untuk orang-orang yang bertakwa, (133) [yaitu] orang-orang yang menafkahkan [hartanya], baik di waktu lapang maupun sempit, dan orang-orang yang menahan amarahnya dan mema'afkan [kesalahan] orang. Allah menyukai orang-orang yang berbuat kebajikan. (134)

b. QS. Al Furqan: 63

"Dan hamba-hamba Tuhan Yang Maha Penyanyang itu (ialah) orang-orang yang berjalan di atas bumi dengan rendah hati."

c. QS. Asy Syura: 37

"Dan apabila mereka marah, mereka memberi maaf."

d. QS. Asy Syura: 40

"Dan balasan suatu kejahatan adalah kejahatan yang serupa, maka barangsiapa memaafkan dan berbuat baik, maka pahalanya atas (tanggungan) Allah. Sesungguhnya Dia tidak menyukai orang-orang yang zhalim."

e. QS. Al Hijr: 88

“Janganlah sekali-kali kamu menujukan pandanganmu kepada keni'matan hidup yang telah Kami berikan kepada beberapa golongan di antara mereka [orang-orang kafir itu], dan janganlah kamu bersedih hati terhadap mereka dan berendah dirilah kamu terhadap orang-orang yang beriman.

f. QS. Lukman: 18-19

"Dan janganlah kamu memalingkan mukamu dari manusia (karena sombong) dan janganlah kamu berjalan dimuka bumi dengan angkuh. Sesungguhnya Allah tidak menyukai setiap orang yang sombong lagi membanggakan diri. Dan sederhanakanlah kamu dalam berjalan dan lunakanlah suaramu. Sesungguhnya seburuk-buruk suara adalah keledai."

Ditinjau dari metode internalisasi nilai-nilai kerohanian Islam, temuan penelitian menunjukkan bahwa metode penanaman nilai-nilai kerohanian Islam yang dilakukan dalam kegiatan ekstrakurikuler kerohanian Islam adalah keteladanan, pembiasaan, pengawasan, nasihat dan hukuman. Keteladanan ditunjukkan dalam kegiatan pemberian contoh berbusana Muslimah kepada siswa, baik oleh guru PAI maupun oleh seluruh guru dalam kegiatan pembelajaran sehari-hari di sekolah. Selain itu lomba fashion busana Muslim, baik yang diselenggarakan sekolah sendiri maupun kepesertaan siswa ke lomba fashion yang diselenggarakan sekolah/lembaga lain juga merupakan sarana pemberian contoh berbusana Muslim yang menarik bagi siswa.

Metode pembiasaan juga terlihat pada pembiasaan menggunakan busana Muslim bagi siswa putri, pembiasaan shalat dhuha dan shalat ashar berjamaah, 
pembiasaan shalat jumat di masjid sekolah, dan pembiasaan membayar zakat fitrah. Metode pengawasan, nasehat, dan hukuman ditunjukkan oleh guru-guru PAl dalam mengawasi aktivitas ekstrakurikuler kerohanian Islam, memberi nasehat dan hukuman kepada siswa yang tidak mengikuti kebijakan sekolah dalam kegiatan ekstrakurikuler kerohanian Islam ini. Jadwal shalat dhuha dan ashar berjamaah sudah ditetapkan, demikian halnya jadwal muazdhin. Untuk menjamin pelaksanaan kegiatan sesuai jadwal, maka guru-guru PAl dibantu guru-guru lainnya melakukan pengawasan, memberi nasehat bagi siswa yang lalai, dan memberi hukuman bagi siswa yang sangat keterlaluan agar tidak diikuti oleh siswa lainnya.

Ditinjau dari tahapan internalisasi nilai-nilai Islam, menurut Muhaimin ${ }^{39}$ dalam internalisasi nilai-nilai kerohanian Islam ada tiga tahap, yaitu transformasi nilai, traksaksi nilai, dan transinternalisasi nilai. Pada tahap transformasi nilai guru sekadar menginformasikan nilai-nilai yang baik dan yang kurang baik kepada siswa, yang semata-mata merupakan komunikasi verbal. Transformasi nilai ini sifatnya hanya pemindahan pengetahuan dari pendidik ke siswanya. Nilai-nilai yang diberikan masih berada pada ranah kognitif dan pengetahuan ini dimungkinkan hilang jika ingatan seseorang tidak kuat.

Hasil penelitian menunjukkan bahwa tahapan transformasi nilai Islam ini telah dilakukan di ruang kelas dalam pembelajaran intrakurikuler dan di luar kelas (ekstrakurikuler) khususnya dalam kegiatan pondok romadhon, peringatan Maulid Nabi, dan khutbah jumat. Pada kegiatan-kegiatan itu proses transfer nilai-nilai kerohanian Islam dilakukan, bahkan lebih bersifat satu arah, dari guru/penceramah ke siswa.

Pada tahap transaksi nilai komunikasi antara guru dan siswa berlangsung dua arah. Dalam transaksi ini guru dan siswa sama-sama memiliki sifat yang aktif. Guru tidak hanya menyajikan informasi tentang nilai yang baik dan buruk, tetapi juga terlibat untuk melaksanakan dan memberikan contoh amalan yang nyata, dan siswa diminta memberikan respons yang sama, yakni menerima dan mengamalkan nilai-nilai itu. ${ }^{40}$ Pada tahap ini guru dapat memberikan pengaruh pada siswa untuk mengamalkan apa yang dicontohkan oleh gurunya, dengan begitu nilainilai religius akan tertanam pada diri siswa dan mampu mengamalkannya dalam kehidupan sehari-hari.

Dalam konteks penelitian ini tahapan transaksi nilai ditunjukkan dalam kegiatan pemberian contoh berbusana Muslimah, belajar baca Al-Quran dalam kegiatan pondok

\footnotetext{
${ }^{39}$ Muhaimin et.al, Paradigma Pendidikan,170-178.

40 Ibid.
} 
romadhon, dan kepanitiaan zakat fitrah sekolah. Pada tahap transinternalisasi nilai, penampilan guru dihadapan siswa bukan lagi dilihat dari sisi fisiknya, melainkan sikap mentalnya (kepribadiannya). Demikian juga siswa merespons kepada guru bukan hanya gerakan/penampilan fisiknya, melainkan sikap mental dan kepriadiannya. Dalam transinternalisasi ini komunikasi terjadi antara dua kepribadian yang masing-masing terlibat aktif. Dalam tahap ini pendidik harus betul-betul memperhatikan sikap dan prilakunya, baik di depan peserta didik maupun dalam kehidupan sehari-harinya. Hal ini disebabkan, siswa cenderung meniru sikap dan kepribadian yang ada pada gurunya, karena guru dianggap sebagai panutan mereka.

Dalam konteks penelitian ini, tahap transinternalisasi nilai-nilai kerohanian Islam terlihat dalam kegiatan pemberian contoh busana muslimah, baik oleh ibu guru PAl maupun oleh ibu-ibu guru mata pelajaran lainnya. Selain itu interaksi antara dua guru PAI laki-laki dengan siswa dalam kegiatan shalat dhuha dan ashar berjamaah. Sebelum shalat kedua guru tersebut memberikan pengetahuan kepada siswa tentang tata-cara shalat dhuha dan atau shalat ashar, kemudian guru menjadi imam. Siswa sedikit demi sedikit akan meniru perilaku guru, baik ketika ceramah maupun ketika menjadi imam shalat.

\section{E. Faktor-faktor Pendukung dan Penghambat; Sebuah Refleksi}

Menurut koordinator guru PAI, terdapat beberapa faktor yang mendukung pelaksanaan internalisasi nilai-nilai Islam melalui kegiatan ekstrakurikuler, di antaranya: ${ }^{41}$ (1) Ada kerjasama yang harmonis dengan sesama guru meskipun belum seluruh guru Muslim untuk memberikan bimbingan kepada siswa dalam menginternalisasikan nilai-nilai agama Islam; (2) Sebagian besar siswa berasal dari keluarga yang agamis, mereka aktif belajar di madrasah diniyah pada sore hari; (3) Adanya dukungan sebagian orang tua siswa untuk turut membimbing dan mengawasi putra-putrinya dalam mengamalkan ajaran Islam di lingkungan keluarga. Hal ini diketahui dari laporan wali murid pada saat rapat wali murid maupun pada saat guru BK melakukan kunjungan ke rumah siswa untuk keperluan bimbingan dan konseling; (4) adanya dukungan masyarakat, khususnya para ustazd; (5) Sekolah menyediakan saranaprasarana yang dibutuhkan siswa dalam menjalankan kegiatan ekstrakurikuler kerohanian Islam seperti masjid, buku-buku agama di perpustakaan, anggaran kegiatan ekstrakurikuler kerohanian Islam dan sebagainya.

${ }^{41}$ Koordinator Guru PAI SMP Negeri 47 Surabaya, Wawancara, Surabaya, 12 Februari 2020. 
Menurut Kepala Sekolah, di antara faktor penghambat pelaksanaan internalisasi nilai-nilai Islam melalui kegiatan ekstrakurikuler kerohanian Islam adalah: ${ }^{42}$ (1) belum seluruh guru mendukung secara tulus kegiatan ekstrakurikuler keagamaan ini, mereka masih berpikiran bahwa kegiatan keagamaan menjadi tanggungjawab guru agama Islam; (2) sebagian orang tua siswa kurang peduli terhadap upaya internalisasi nilainilai agama Islam anaknya di rumah meskipun sekolah telah meminta mereka untuk berpartisipasi dalam mendidik putra-putrinya dalam mengamalkan ajaran Islam. Kebiasaan shalat dhuha dan shalat berjamaah di sekolah tidak diteruskan di rumah; (3) guru PAl belum melakukan evaluasi keefektifan kegiatan ekstrakurikuler keagamaan dalam menginternalisasikan nilai-nilai agama Islam kepada siswa.

Atas apa yang dikemukakan Kepala Sekolah tersebut, koordinator guru PAI sekolah mengiyakannya. la mengemukakan alasan belum dilakukannya evaluasi tersebut karena kegiatan ekstrakurikuler kerohanian Islam sifatnya untuk menambah, memperkuat pengetahuan agama yang telah didapat siswa dalam kegiatan kurikuler PAl. Evaluasi sudah dilakukan di kelas dalam pembelajaran PAI meskipun sifatnya lebih kognitif.

\section{F. Kesimpulan}

Sebagai bagian akhir tulsan ini, penulis menyimpulkan bahwa, proses internalisasi nilai-nilai agama Islam melalui kegiatan eksrakurikuler kerohanian Islam di SMPN 47 Surabaya mencakup nilai akidah, nilai syariah, dan nilai akhlak dengan menggunakan metode keteladanan, pembiasaan, pengawasan, nasihat dan hukuman. Adapun tahapannya dilakukan melalui tiga tahap, yaitu: transformasi nilai, transaksi nilai, dan transinternalisasi nilai. Ketiga tahapan tersebut didukung oleh kerjasama yang harmonis dengan sesama guru; sebagian besar siswa berasal dari keluarga yang agamis, mereka aktif belajar di madrasah diniyah pada sore hari dan ketersediaan sarana-prasarana yang dibutuhkan siswa dalam menjalankan kegiatan ekstrakurikuler kerohanian Islam, seperti masjid, buku-buku agama di perpustakaan, dan anggaran kegiatan ekstrakurikuler kerohanian Islam. Agar program tersebut lebih efektif, penulis merekomendasikan beberapa hal: Pertama, perlu adanya sinergitas antara guru dan orang tua agar upaya internalisasi nilai-nilai agama Islam berkelanjutan di lingkungan keluarga. Kedua, perlu adanya evaluasi berkala, sehingga kekurangan dan kelebihannya dapat diketahui secara tepat.

\footnotetext{
${ }^{42}$ Kepala SMP Negeri 47 Surabaya, Wawancara, Surabaya, 26 Februari 2020.
} 


\section{G. Referensi}

Ahmadi, Abu dan Salimi, Noor. Dasar-Dasar Pendidikan Agama Islam., Jakarta: Bumi Aksara, 2008.

Al-Abrasyi, M. Athiyah. Pendidikan Islam, Terj.: Bustami dan Johar Bahry. Jakarta: Bulan Bintang, 1990.

Al-Ghazali. Ihya' Ulumuddin (Juz. I), Terj.: Ismail Yakub. Jakarta: CV. Faizan, 1985.

Ali, Muhammadiyah Daud. Pendidikan Agama Islam. Jakarta: PT. Raja Grafindo Persada, 2010.

Alim, Muhammad. Pendidikan Agama Islam: Upaya Pembentukan Pemikiran dan Kepribadian Muslim. Bandung: PT Remaja Rosdakarya, 2011.

Aly, Abdullah dan Hidayat Syamsul. Al-Ubudiyah. Surakarta: Lembaga Pengembangan Ilmu-Ilmu Dasar (LPID) UMS, 2006.

Aminuddin. Pendidikan Agama Islam: Untuk Perguruan Tinggi Umum. Bogor: Ghalia Indonesia, 2005.

AR, Zaini Tamin. "Teologi Pengembangan Pemuda; Membumikan Tauhid sebagai Dasar Kesalihan Sosial”, Mukammil : Jurnal Kajian Keislaman, Vol. 1 No. 2 (2018): 121142.

Aziz, Erwati. Prinsip-Prinsip Pendidikan Islam. Solo: Tiga Serangkai Pustaka, 2003.

Aziz, Abdul. Filsafat Pendidikan Islam: Sebuah Gagasan Membangun Pendidikan Islam/ Surabaya: eLKAF, 2006.

Darajat, Zakiyah. Ilmu Pendidikan Islam. Jakarta: Bumi Aksara, 2011.

Daryanto. Evaluasi Pendidikan. Jakarta: Rineka Cipta, 2001.

Departemen Agama. Panduan Kegiatan Ekstrakurikuler Pendidikan Agama Islam. Jakarta: Direktorat Jenderal Kelembagaan Agama Islam, 2005.

Departemen Agama. Al-Qur'an Al- Karim dan Terjemahannya Kedalam Bahasa Indonesia, Riyadh: Kerajaan Saudi Arabiyah, 1980.

Gazalba, Sidi. Anzis Agama Islam. Jakarta; Bulan Bintang, 1975.

Hanafi, M. Arif, et, al. "Optimalisasi Kegiatan Keagamaan dalam Meningkatkan Sikap Spiritual Siswa di SMPN 3 Waru Sidoarjo", (2021).

J.P. Chaplin. Kamus Lengkap Psikologi, Jakarta: Rajawali Press, 2011.

Majid, Abdul. Pendidikan Karakter Prespektif Islam. Bandung: PT. Remaja Rosdakarya, 2011.

Muchtar, Heri Jauhari. Fikih Pendidikan. Bandung: PT. Remaja Rosdakarya, 2008.

Muhaimin et.al,. Paradigma Pendidikan Islam. Bandung: Remaja Rosdakarya, 2012 
Muhaimin. Paradigma Pendidikan Islam, Bandung: PT. Remaja Rosdakarya. 2001.

Mulyana, Rohmat. Mengartikulasikan Pendidikan Nilai. Bandung: CV Alfabeta, 2004.

Nata, Abuddin. Manajemen Pendidikan: Mengatasi Kelemahan Pendidikan Islam di Indonesia. Jakarta: Kencana, 2007.

Purnamasari, Nia Indah. "Komparasi Konsep Sosiokulturalisme dalam Pendidikan: Perspektif Barat dan Islam", EL-BANAT: Jurnal Pemikiran dan Pendidikan Islam, Vol. 9 No. 2 (2019), 238-261.

Ramayulis. Metodologi Pendidikan Agama Islam. Jakarta : Kalam Mulia. Shafan, Moh, (2007). The Realistic Educatin. Jogyakarta: Ircisod, 2005.

Rifa'i, Muh. Khoirul. "Internalisasi Nilai-nilai Religius Berbasis Multikultural dalam Membentuk Insan Kamil", Jurnal Pendidikan Agama Islam (Journal of Islamic Education Studies), Vol. 4 No. 1 (2016).

Rusydiyah, Evi Fatimatur. Aliran Dan Paradigma Pemikiran Pendidikan Agama Islam Kontemporer. Surabaya: Sunan Ampel Press, 2019.

Sahlan, Asmaun. Mewujudkan Budaya Religius di Sekolah: Upaya Mengembangkan PAI dari Teori ke Aksi. Malang: UIN-Maliki Press, 2010.

Shaleh, Abdul Rachman. Madrasah dan Pendidikan Anak Bangsa : Visi, Misi,dan Aksi. Jakarta : PT. Raja Grafindo Persada, 2005.

Suhendi, Hendi. Fiqh Muamalah. Jakarta: PT.Raja Grafindo Persada, 2005.

Tafsir, Ahmad. Ilmu Pendidikan dalam Perspektif Islam. Bandung: PT. Rosda Karya, 2008.

Thobroni, Ahmad Yusam. "Etika Pelajar Dalam Perspektif Ibn Jama'ah", Jurnal Pendidikan Agama Islam (Journal of Islamic Education Studies), Vol. 1 No. 2 (2013)

Usman, Moh. Uzer. Menjadi Guru Profesional. Bandung: PT. Remaja Rosdakarya, 2011.

Wiyani, Novan Ardy dan Barnawi. Ilmu Pendidikan Islam: Rancang Bangun Konsep Pendidikan Monokotomik-Holistik. Jogjakarta: Ar-Ruzz Media, 2012.

Zuhairini dan Abdul Ghafir. Metodologi Pembelajaran Pendidikan Agama Islam. Malang: UM Press, 2004.

Zulkarnain. Transformasi Nilai-Nilai Pendidikan Islam: Manajemen Berorientasi Link and Match. Yogyakarta: Pustaka Belajar, 2008. 